\title{
TINGKAT STRES PENDERITA DIABETES MELITUS DI PANTI WERDA SANTU YOSEF SURABAYA
}

\author{
Ni Nyoman Wahyu Lestarina \\ Program Studi Ilmu Keperawatan STIKES Katolik St. Vincentius a Paulo Surabaya \\ e-mail: wahyulestarina@gmail.com
}

\begin{abstract}
ABSTRAK
Diabetes Melitus (DM) adalah penyakit metabolik dengan tanda terjadi hiperglikemia. Terdapat banyak kendala yang dapat muncul saat menjalani program penatalaksanaan DM dan hal tersebut dapat menimbulkan stress pada penderita. Kesulitan dan tingkat keterlibatan penderita dalam menjalani tatalaksanan dapat mengakibatkan tingginya ketidakpatuhan terapi pada pasien yang mengalami stres. Tujuan penelitian ini adalah untuk mengetahui gambaran tingkat stres penderita diabetes melitus di Panti Werda St. Yosef Surabaya. Desain penelitian menggunakan desain deskriptif dengan jumlah responden sebanyak 30 orang. Teknik sampling menggunakan simple random sampling. Instrumen penelitian menggunakan kuesioner Depression Anxiety Stress Scale (DASS) 21. Analisa data menggunakan Analisis Statistik Deskripsi Proporsi Prosentase (ASDPP). Dari hasil penelitian didapatkan sebagian besar (70\%) lansia penderita Diabetes Melitus yang berada di Panti Werda St. Yosef berada pada kategori normal. Permasalahan stres pada penderita diabetes ini juga erat kaitannya dengan cara atau strategi pemecahan masalah (coping) yang dilakukan oleh penderita diabetes. Menurutnya, coping yang dilakukan oleh penderita diabetes merupakan usaha pasif atau aktif yang dilakukannya dalam menghadapi situasi yang dirasa menyebabkan stres. Petugas panti werda St. Yosef sudah melakukan perawatan yang baik bagi penderita DM. Pemeriksaan kesehatan rutin dilakukan, pengontrolan obat dan diet serta pelaksanaan aktivitas bagi lansia juga telah dilakukan. Hal ini dapat membuat penderita DM dapat beradaptasi dengan keadaannya sehingga penderita DM tidak mengalami stres dalam menjalani pengobatannya.
\end{abstract}

Kata Kunci: Stres, Diabetes Melitus

\begin{abstract}
Diabetes mellitus (DM) is metabolic diseases with signs of hyperglycemia. There are many obstacles that can arise when undergoing a DM management program and this can cause stress to patients. Difficulties and levels of involvement of patients in undergoing treatment can result in high noncompliance in patients who experience stress. The purpose of this study was to determine the stress level of diabetic mellitus sufferers at the St. George Hospital. Yosef Surabaya. The study design used a descriptive design with 30 respondents. The sampling technique uses simple random sampling. The research instrument used a questionnaire Depression Anxiety Stress Scale (DASS) 21. Analysis of data using Statistical Analysis Description of Proportion Percentage (ASDPP). From the results of the study, it was found that most (70\%) elderly people with Diabetes Mellitus who were on the Werda St. Joseph is in the normal category. The problem of stress in diabetics is also closely related to the way or problem solving strategies (coping) carried out by diabetics. According to him, coping carried out by diabetics is a passive or active business that he does in dealing with situations that are felt to cause stress. St. Petersburg nursing staff Yosef has done good care for people with DM. Routine health checks are carried out, control of drugs and diet and the implementation of activities for the elderly have also been carried out. This can make DM patients adapt to the situation so that people with DM do not experience stress in undergoing treatment.
\end{abstract}

Keyword: Stress, Diabetes Mellitus 


\section{PENDAHULUAN}

Diabetes Melitus (DM) merupakan penyakit metabolik yang terjadi akibat kelainan sekresi atau kerja insulin yang ditandai dengan peningkatan gula darah (Soegondo et al., 2002). DM tipe 2 merupakan jenis DM yang paling sering terjadi dan jumlahnya mengalami peningkatan setiap tahunnya (Nolan et al., 2011; D'Adamo and Caprio, 2011). Diabetes sering menimbulkan komplikasi sehingga memerlukan dukungan edukasi berkaitan dengan perawatan dan pengobatan jangka panjang klien DM (Perkeni, 2011). Hal ini yang dapat mempengaruhi fisik dan psikologis penderita DM (de Groot et al., 2010; Angraeni and Cahyanti, 2012). Stres dapat timbul selama melaksanakan pengobatan akibat kesulitan dalam menjalani tatalaksana tersebut (Widodo, 2012). Kesulitan dan tingkat keterlibatan penderita dalam menjalani tatalaksanan dapat mengakibatkan tingginya ketidakpatuhan terapi pada pasien yang mengalami stres (Knerr, M., 2009).

Menjelang tahun 2010 angka diabetesi mencapai angka 239,3 juta. Diperkirakan pada tahun 2025 angka diabetesi meningkat hingga 300 juta. Indonesia menempati peringkat ke 7 pengidap diabetes yaitu sebanyak 4,5 juta jiwa dan diprediksi akan menjadi peringkat 5 pada tahun 2025 (Arisman, 2010). Prevalensi DM di Jawa Timur menurut data Riset Kesehatan Dasar tahun 2013 sebesar 2,1\% terjadi pada usia > 16 tahun (Saifunurmazah, 2013). Penelitian yang dilakukan Widodo tahun 2012 di RSUP Dr. Kariadi Semarang didapatkan $40 \%$ mengalami stress karena perubahan pola makan (Widodo, 2012). Penelitian yang dilakukan Setyoningrum tentang tingkat depresi pada pasien ulkus diabetikum di Poli Bedah RSUD Kota Semarang, sebagian besar pasien mengalami depresi berat yaitu sebanyak $46,7 \%$.

Penyebab DM tersering adalah akibat kegemukan, pola makan yang salah dan gaya hidup yang kurang sehat selain juga karena faktor genetik (Widodo, 2012). Stres dapat menyebabkan gangguan dalam pengontrolan gula darah. Stres menyebabkan terjadinya peningkatan ekskresi hormon kategolamin, glukagon, glukokortikoid, endorfin dan hormon pertumbuhan. Apabila DM tidak terkontrol, akan menyebabkan komplikasi pada pasien. Komplikasi akut penyakit DM antara lain hipoglikemia, ketoasidosis, dan koma. Komplikasi kronis yang dapat terjadi adalah kerusakan saraf, penyakit jantung, gangguan hepar, gagal ginjal, gangguan pencernaan, dan rentan terhadap infeksi (Nolan et al., 2011).

Stres dapat dicegah ataupun dikurangi dengan pengelolaan yang baik. Terdapat beberapa cara untuk melakukan manajemen stres pada penderita DM yaitu dengan mengubah pandangan pasien terhadap penyakit yang diderita, meningkatkan dukungan sosial dari sesama penderita dan keluarga serta menerapkan strategi koping yang baik misalnya dengan melakukan kegiatan positif yang disenangi dan teknik relaksasi (Widodo, 2012). Tujuan penelitian ini untuk mengetahui gambaran tingkat stres penderita diabetes melitus di Panti Werda Santo Yosef Surabaya.

\section{BAHAN DAN METODE}

Desain penelitian dalam penelitian ini menggunakan rancangan penelitian deskriptif. Penelitian ini menggambarkan tingkat stres penderita diabetes melitus di Panti Werda Santu Yosef Surabaya. Variabel dalam penelitian ini adalah tingkat stress klien diabetes melitus. jumlah responden dalam penelitian adalah 30 responden. Kriteria inklusi penelitian ini yaitu: Penderita DM tanpa komplikasi, Bisa membaca dan menulis. Kriteria eksklusi dalam penelitian ini adalah Klien dengan gangguan pendengaran, muskuloskeletal, kejiwaan. Teknik sampling yang digunakan adalah simple random sampling. Lokasi penelitian berada di Panti Werda Santo Yosef Surabaya. Penelitian dilaksakan pada tanggal 10- 15 November 2017. Alat ukur dalam penelitian ini menggunakan kuesioner Depression Anxiety Stress Scale (DASS) 21. Terdapat 21 pernyataan dalam DASS 21 yang dapat digunakan untuk mengukur tingkat depresi, cemas dan stres. Nilai yang didapatkan pada setiap kelompok yaitu depresi, cemas dan stres, harus dikalikan 2 sebelum dikategorikan. Penghitungan uji validitas kuesioner menggunakan korelasi Pearson product moment. Hasil validitas didapatkan > 0,36 yang menyatakan bahwa pertanyaan dalam kuesioner ini valid. Uji reliabilitas instrumen menggunakan koefisien Alpha Cronbach dengan hasil 0.75 sehingga dapat 
dikatakan kuesioner yang digunakan dalam penelitian ini reliabel. Analisa data menggunakan analisis statistik deskriptif proporsi prosentase. Data-data yang disajikan meliputi frekuensi, proporsi dan rasio, ukuran-ukuran kecenderungan pusat (rata-rata hitung, median,modus), maupun ukuran-ukuran variasi (simpangan baku, variansi, rentang, dan kuartil). Setelah hasinya ditabulasi maka data dianalisa untuk mengetahui jumlah responden yang termasuk tingkat tertentu dengan menggunakan rumus proporsi prosentase.

\section{HASIL}

Tabel 1. Data Demografi klien DM di Panti Werda Santu Yosef Surabaya

\begin{tabular}{llll}
\hline No. & Karakteristik & Jumlah & Persen \\
\hline 1. & Jenis Kelamin & & \\
& Perempuan & 20 & $66,7 \%$ \\
& Laki- laki & 10 & $33,3 \%$ \\
2. & Tingkat & & \\
& Pendidikan & & \\
& SD & 5 & $16,7 \%$ \\
& SMP & 9 & $30 \%$ \\
& SMA & 8 & $26,7 \%$ \\
& PT & 8 & $26,7 \%$ \\
3. Usia & & \\
& 56-65 tahun & 5 & $16,7 \%$ \\
& $>65$ tahun & 25 & $83,3 \%$ \\
\hline
\end{tabular}

Berdasarkan tabel 1 didapatkan sebagian besar penderita DM berjenis kelamin perempuan sebanyak 20 orang dengan usia terbanyak adalah > 65 tahun sebanyak 25 orang.

Tabel 2. Gambaran Tingkat Stres Klien DM di Panti Werda Santu Yosef Surabaya

\begin{tabular}{llll}
\hline No. & Kategori & Jumlah & Persen \\
\hline Normal & 21 & $70 \%$ \\
Stres ringan & 4 & $13,3 \%$ \\
Stres sedang & 3 & $10 \%$ \\
Stres berat & 0 & $0 \%$ \\
Stres sangat & 2 & $6,7 \%$ \\
berat & & \\
\hline
\end{tabular}

Berdasarkan tabel 2 didapatkan tingkat stres penderita DM di panti werda Santu Yosef Surabaya berada pada tingkat normal yaitu sebanyak 21 orang.

\section{PEMBAHASAN}

Dari hasil penelitian didapatkan sebagian besar penderita DM diderita oleh perempuan. Perempuan beresiko terkena diabetes dibandingkan dengan laki- laki karena perempuan mempunyai resiko peningkatan indeks massa tubuh yang lebih besar. Premenstrual syndrome dan menopause juga membuat distribusi lemak menjadi mudah terakumulasi (Irawan, 2010). Dari hasil penelitian didapatkan tingkat stres pada penderita DM sebagian besar dalam kategori normal, akan tetapi ada penderita yang masuk dalam kategori stre ringa, sedang sampai stres sangat berat. Stres adalah perasaan yang dihasilkan ketika seseorang bereaksi terhadap peristiwa tertentu. Peristiwa yang memancing stres dapat berupa situasi fisik seperti sakit atau cedera (Mitra, 2008). Vranic et al. (2000) mengatakan bahwa stress dapat mengakibatkan gangguan pengontrolan kadar gula darah. Stress menyebabkan peningkatan ekskresi hormon katekolamin, gkukagon, glukokortikoid, $\beta$ endorfin dan hormon pertumbuhan. Hormonhormon tersebut yang menyebabkan peningkatan kadar gula darah. Permasalahan stres pada penderita diabetes ini juga erat kaitannya dengan cara atau strategi pemecahan masalah (coping) yang dilakukan oleh penderita diabetes. Menurutnya, coping yang dilakukan oleh penderita diabetes merupakan usaha pasif atau aktif yang dilakukannya dalam menghadapi situasi yang dirasa menyebabkan stres (Bianchi, 2004). Petugas panti werda Santu Yosef sudah melakukan perawatan yang baik bagi penderita DM. pemeriksaan kesehatan rutin dilakukan, pengontrolan obat dan diet serta pelaksanaan aktivitas bagi lansia juga telah dilakukan. Hal ini dapat membuat penderita DM dapat beradaptasi dengan keadaannya sehingga penderita DM tidak mengalami stres dalam menjalani pengobatannya.

Dari hasil penelitian didapatkan 2 orang penderita DM mengalami stres sangat berat. Dilihat dari lama menderita DM, penderita tersebut baru menderita DM selama 3-4 bulan. Pada waktu seseorang memasuki masa usia lanjut, terjadi berbagai perubahan baik yang bersifat fisik, mental, maupun sosial. Apabila lansia tidak siap akan perubahanperubahan yang dialami, justru akan menjadi sumber akumulasi stres dan frustasi (Indriana, 2008). Penderita DM yang baru didiagnosa menderita DM, akan mengalami perubahan dalam hidupnya. Perubahan dalam pengobatan, pola makan serta aktivitas membuat penderita menjadi frustasi. Apabila 
penderita DM tidak mampu beradaptasi dengan keadaannya, akan timbul stres.

\section{KESIMPULAN DAN SARAN}

Dari hasil penelitian didapatkan sebagian besar (70\%) lansia penderita Diabetes Melitus yang berada di Panti Werda St. Yosef berada pada kategori normal. Untuk petugas panti yang berada di Panti Werda Santu Yosef selalu mendampingi lansia dalam beradaptasi dengan diri dan lingkungannya sekarang (panti) melalui penyediaan dan peningkatan layanan-layanan baik psikologis, medis, maupun sosial sehingga terhindar dari stres dan kualitas hidup lansia yang dapat terjaga optimal.

\section{DAFTAR PUSTAKA}

Angraeni, T. and Cahyanti, I. Y. (2012). Perbedaan Psychological Well-Being Pada Penderita Diabetes Tipe 2 Usia Dewasa Madya Ditinjau dari Strategi Coping. Jurnal Psikologi Klinis dan Kesehatan Mental, 1 (02).

Arisman. (2010). Obesitas, Diabetes Melitus \& dislipidemia: Konsep, Teori dan penanganan Aplikasi. Mahode, A. A. (ed.). Jakarta: EGC.

Bianchi. (2004). Stress and Coping Among Cardiovascular Nurses: a Survey In Brazil. Issues in Mental Health Nursing, 25, p.737-745.

D'Adamo, E. and Caprio, S. (2011). Type 2 Diabetes in Youth: Epidemiology and Pathophysiology. Diabetes Care, 34 (Supplement_2), p.S161-S165. [Online]. Available at: doi:10.2337/dc11-s212.

de Groot, M., Kushnick, M., Doyle, T., Merrill, J., McGlynn, M., Shubrook, J. and Schwartz, F. (2010). Depression Among Adults With Diabetes: Prevalence, Impact, and Treatment Options. Diabetes spectrum: a publication of the American Diabetes Association, 23 (1), p.15-18. [Online]. Available at: doi:10.2337/diaspect.23.1.15 [Accessed: 27 October 2015].

Indriana. (2008). Gerontologi: Memahami Kehidupan Usia Lanjut. Semarang: Penerbit Universitas Diponegoro.

Irawan, D. (2010). Prevalensi Dan Faktor Resiko Kejadian Diabetes Melitus Tipe 2 di Daerah Urban Indonesia.
Universitas Indonesia.

Knerr, M., et al. (2009). The Impact of Initial Factors of Therapeutic Alliance in Individuals and Couples Therapy. Journal of Marital and Family Therapy, p.1-18.

Mitra, A. (2008). Diabetes and Stress: a Review. Ethno-Med, 2 (2), p.131-135.

Nolan, C. J., Damm, P. and Prentki, M. (2011). Type 2 diabetes across generations: from pathophysiology to prevention and management. The Lancet, 378 (9786), Elsevier Ltd, p.169181. [Online]. Available at: doi:10.1016/S0140-6736(11)60614-4.

Perkeni. (2011). Konsensus Pengelolaan Diabetes Melitus (DM) di Indonesia. Jakarta: PERKENI.

Saifunurmazah, D. (2013). Kepatuhan Penderita Diabetes Mellitus Dalam Menjalani Terapi Olahraga dan Diet. Universitas Negeri Semarang.

Soegondo, S., Soegondo, P. and Subekti, I. (2002). Penatalaksanaan Diabetes Melitus Terpadu. 2nd ed. Soegondo, S., Soegondo, P. and Subekti, I. (eds.). Jakarta: Balai Penerbit FKUI.

Widodo, A. (2012). Stress Pada Penderita Diabetes Mellitus tipe-2 Dalam Melaksanakan Program Diet di Klinik Penyakit Dalam RSUP Dr. Kariadi Semarang. Medica Hospitalia, 1 (1), p.53-56. 